\title{
Development of Motor Learning Model Based on Game and Fun Activities
}

\author{
Darni $^{1 *}$, Gusti Handayani ${ }^{1}$ \\ ${ }^{I}$ Sport Science Faculty, Universitas Negeri Padang, Indonesia \\ "Corresponding author. Email: darniroesi@gmail.com
}

\begin{abstract}
Based on the previous observations, problems regrarding the motor skills learning model is The problem of this research was the lack of motor skills learning model found in kindergarten (TK). This study aims at developing a gamed-based motor skill learning model namely "game and fun" to nursery students. The stages of the research were 1) conducting preliminary study to find problems, to collect data and to do needs analysis, (2) planning the learning model, (3) field testing, expert judgment, and product revisions, and (4) implementing the developed model. The draft field testing was conducted at TK Quwwatul Ummah involving 15 students. The small group sample was tested at TK Samudera involving 15 students. Last, the main field testing was conducted in two places: 1) TK Dharmawanita by involving 20 students and 2) TK Perwari by involving 15 students. The results of this study show that: a) there were ten games produced by the developed training model using animals-theme b) the development of game-based fundamental motor skills learning model was effective to be applied in kindergarten, c) the development of game-based fundamental motor skills learning model using "game and fun" game received good response from preschoolers.
\end{abstract}

\section{Keywords: Motor Learning, Game and Fun}

\section{INTRODUCTION}

Education for children starts from home and continues to nursery school or Kindergarten as well as the surrounding environment. Once the children begin their education in kindergarten, they cannot be taught rigidly. One of many learning methods that can be applied to children of early age is through playing. Learning by playing can be fun and entertaining for children. Playing for children is a serious but fun activity. A good learning activity will consider the freedom of children to choose their activities.

"Kindergarten is one of the formal education levels aimed at children aged 4-6 years" [1]. At the level of kindergarten, the learning stages are divided into two groups. The first stage is group A intended for children aged 4-5 years and the second stage is group B intended for children aged 5-6 years. The division at the kindergarten education level is aimed at justifying the learning activities based on the physical and psychological development of children. The curriculum is a planned, written and systematic learning activity. Especially related to kindergarten, the curriculum is a whole business or school activities to stimulate children to learn in order to develop all aspects, both inside and outside the class and the environment.

The determination of the basic framework and structure of learning programs in the curriculum by Kemendikbud is done by taking into account of several provisions including valid, importance level, significance of materials, and the worthy of study. The provision of teaching materials stipulated by the Government through Kemendikbud aims at developing several aspects that refer to the standards of competence. Aspects to be developed in kindergarten are religious and moral value, physical and motor skill, language, and social emotional.

Physical and motor aspects are the benchmarks/standard to stimulate motor development of preschoolers. The proper stimulation according to the growth and development of children in the learning process will optimize the learning outcomes. Various models of fundamental and physical motor learning are taught in kindergarten institutions including fine motor learning and rough motor learning.

Rough motor learning is learning through physical activity involving large muscles that can be done through physical activity, such as running and jumping. Due to the importance of motor skill development for preschoolers, the government through Kemendikbud built a standardization and achievement program for kindergarten. The standardization program created is incorporated into the basic framework and learning program in kindergarten. The standardization of achievement programs made by the government is quite complex and good, it is proof from the concepts and standardized objectives. Nevertheless, the implementation of the program certainly does not always run smoothly. Sometimes, there are some constraints found when the program is implemented.

The problems that occur in the program are influenced by various factors, such as the lack of school facilities, fundamental motor skill learning model, teacher's understanding about the development of fundamental motor skills learning, and enthusiasm for the students following the motor skill activities (usually this comes from the students themselves). Learning by playing is not only fun 
but also very beneficial for the development of children. For that reason, it is good if learning by play is applied in every learning session. Even, everything that gains students' interests can be used as a game. The game does not have to be in the form of modern tools, but the game can be things that are playful and fun. As long as it is fun for the child and has the value of learning, it can also be said as a game.

Based on the results of observation, there were some problems occurred during the fundamental motor skill learning in kindergarten. The problems consisted of the lack of learning model for fundamental motor skill. It can be seen from teachers' difficulties to find appropriate learning model. Besides, the lack of a child's willingness to move was visible from many passive students during the learning process. In addition, the irregularity of motor skill learning stages was assumed as the less-programmed instructional sequences. Lack of standardization in motor skill learning was showed by the low the achievement of motor learning outcomes. Moreover, the lack of development in learning model can be seen from the less-varied type of fundamental motor skill learning. Based on the background described above, the researchers intended to conduct research entitle Developing A Game-based Fundamental Motor Skills Learning Model Using "Game and Fun" Game.

\section{METHODOLOGY}

The type of research used was Research and Development design. "Establishes research and development procedures consisting of the following steps: (1) conducting preliminary study, (2) collecting data, (3) designing product, (4) validating the design , (5) revising the Design, (6) preliminary field testing, (7) revising main product, (8) main field testing, (9) final product revision, and (10) mass production. In purposes of developing this agility test, the researchers adapted the steps proposed by Sugiyono. However, not all of the steps were done because of the limited cost and time. The steps were carried out in 4 stages: (1) conducting the preliminary study to find out the problem, collect the data and conduct needs analysis, (2) planning the test tool, (3) conducting field testing, expert evaluation, and product revision, and (4) implementing the developed learning model"'[2]. The preliminary draft testing was conducted at TK Quwwatul Ummah involving 15 students accompanied by two teachers. There were two small-scale groups tests performed to determine whether the product is feasible to be used in the actual situation. These small-scale group tests were conducted in TK Samudera involving 15 students accompanied by two teachers. The large-scale group test was performed on a larger scope. A large-scale group test was conducted to determine whether the products produced can be used and is effective on a wider scope. The large-scale testing was conducted in two places: 1) TK Dharmawanita involving 20 students who were taught by two teachers and 2) TK Perwari involving 15 students who were taught by two teachers.

\section{RESULT}

\section{Preliminary (Draft) Product Description}

The first product description is a preliminary draft of the developed model to be undertaken. In developing the model, it consisted of 10 basic motion game models based on game and fun games. Here are 10 basic motion game models for preschoolers: 1) Run and Throw the Ball Game 2) Leaping Games, 3) Color Equal Game, 4) Mice Hole Game, 5) Throwing ball game, 6) "Undur-undur" game, 7) Snake Hunting game, 8) Tiger and Goat game, 9) Shuttle run and throw ball game, and 10) Jumping Rope Game.

Experts' Suggestion for the Developed Model

The next step after creating a draft and recording the draft into CDs was to seek opinions and suggestions from experts. Expert opinions and suggestions were used to improve the quality of products made. Here are opinions and suggestions from experts on the draft of the fundamental motor skill learning model to pre-schoolers.

Table 1. Experts' Suggestions on First Draft Model

\begin{tabular}{lll}
\hline No & Experts & Input \\
\hline 1 & Expert 1 & $\begin{array}{l}\text { It is needed to add the game } \\
\text { duration } \\
\text { It is needed to justify the sum of } \\
\text { the game to the learning session } \\
\text { in kindergarten }\end{array}$ \\
\hline 2 & Expert 2 & $\begin{array}{l}\text { It is needed to set the objectives } \\
\text { to be more specific } \\
\text { It is needed to stress out the } \\
\text { advantages of the model }\end{array}$ \\
\hline 3 & Kindergarten & $\begin{array}{l}\text { It is needed to justify the } \\
\text { developed model to the } \\
\text { Teachers }\end{array}$ \\
& & $\begin{array}{l}\text { kurriculum applied in } \\
\text { kindergarten }\end{array}$ \\
\hline
\end{tabular}

Based on the input of the experts, the developed model was improved. The improvements were made in the instruction to implement the model and in learning objectives to comply it to the curriculum used in kindergarten. The next step after the first draft was improved was to test the product. The table below shows the result of the product testing:

Table 2. Categorized Normative Calculations By Experts and Teachers for Each Game In Product Testing

\begin{tabular}{lll}
\hline Formula & Interval & Category \\
\hline$X<(\mu-1,0 \sigma)$ & $X<25$ & Less appropriate \\
\hline $\begin{array}{l}(\mu-1,0 \sigma) \leq X< \\
(\mu+1,0 \sigma)\end{array}$ & $25 \leq X<35$ & Fairly Appropriate \\
\hline$(\mu+1,0 \sigma) \leq X$ & $35 \leq X$ & Appropriate \\
\hline
\end{tabular}

Note:

$X$ : Number of subject scores $\mu$ : Ideal mean $\sigma$ : Deviation Standard.

Based on the categorized normative calculation above, it shows the frequency distribution of assessment provided by experts and teachers. Next, the following table presents the assessment frequency distribution. 
Table 3. Frequency Distribution of Conformity Assessment of Draft Test

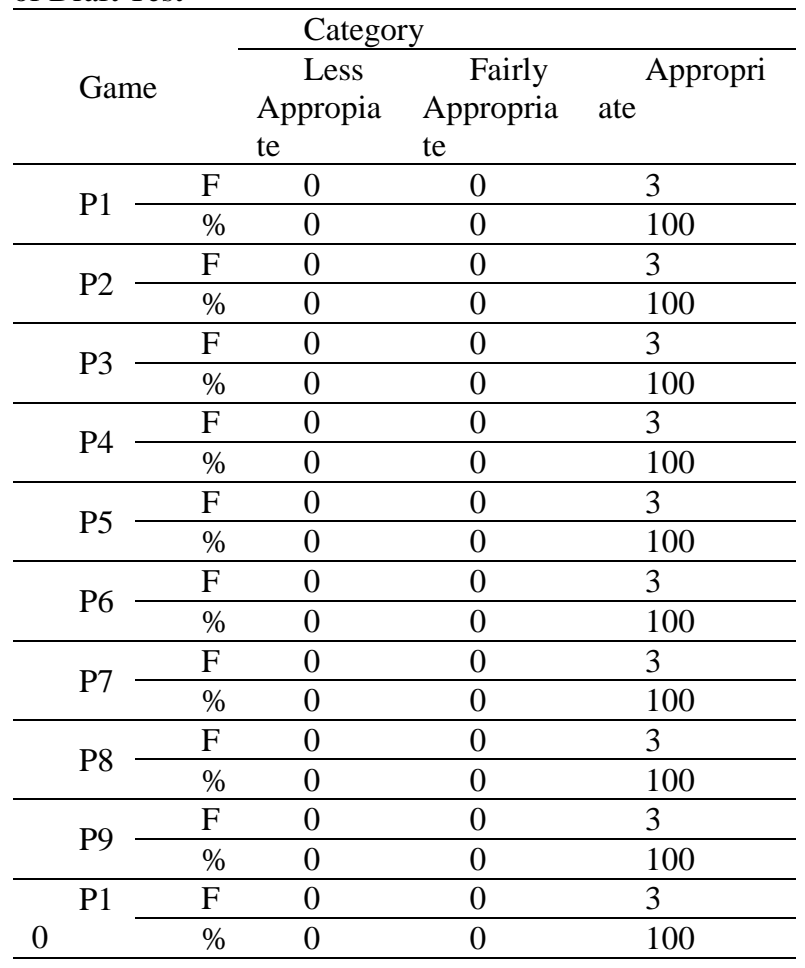

Note:

F: Frequency, \%: Percent

Based on the frequency distribution calculation above, it was found that the fundamental motor skill learning model using "game and fun" game to Preschoolers was at $\mathrm{X}<35$ interval or in appropriate category. Based on this result, the researcher conducted a small-scale group testing.

\section{Small-Scale Group Testing Data}

After the first draft of the learning model was validated, the next step was to conduct small-scale testing. In this study, the small-scale testings were conducted in TK Samudera involving 20 students taught by two teachers. There were three kinds of data obtained from the smallscale testing, namely: (1) observation data of the developed model in its implementation, (2) the data of the effectiveness of learning model in its implementation, (3) input data on the developed model after being implemented in kindergarten. The small-scale testing data was obtained from 10 items of questions given to the experts. There were four different scoring scales for each item. The obtained data wass then processed by using Likert scale. The following presents validation interval and assessment frequency distribution by experts.
Table 4. Assessment Frequency Distribution by Experts and Teacher at Each Game In Small Scale testing

\begin{tabular}{|c|c|c|c|c|}
\hline \multirow{2}{*}{\multicolumn{2}{|c|}{ Game }} & \multicolumn{3}{|c|}{ Category } \\
\hline & & \multirow{2}{*}{$\begin{array}{c}\text { Less } \\
\text { Appropriate } \\
0\end{array}$} & \multirow{2}{*}{$\begin{array}{c}\begin{array}{c}\text { Fairly } \\
\text { Appropriate }\end{array} \\
0\end{array}$} & \multirow{2}{*}{$\begin{array}{c}\text { Appropriate } \\
3\end{array}$} \\
\hline \multirow{2}{*}{ P1 } & $\mathrm{F}$ & & & \\
\hline & $\%$ & 0 & 0 & 100 \\
\hline \multirow{2}{*}{$\mathrm{P} 2$} & $\mathrm{~F}$ & 0 & 0 & 3 \\
\hline & $\%$ & 0 & 0 & 100 \\
\hline \multirow{2}{*}{ P3 } & $\mathrm{F}$ & 0 & 0 & 3 \\
\hline & $\%$ & 0 & 0 & 100 \\
\hline \multirow{2}{*}{ P4 } & $\mathrm{F}$ & 0 & 0 & 3 \\
\hline & $\%$ & 0 & 0 & 100 \\
\hline \multirow{2}{*}{ P5 } & $\mathrm{F}$ & 0 & 0 & 3 \\
\hline & $\%$ & 0 & 0 & 100 \\
\hline \multirow{2}{*}{ P6 } & $\mathrm{F}$ & 0 & 0 & 3 \\
\hline & $\%$ & 0 & 0 & 100 \\
\hline \multirow{2}{*}{ P7 } & $\mathrm{F}$ & 0 & 0 & 3 \\
\hline & $\%$ & 0 & 0 & 100 \\
\hline \multirow{2}{*}{ P8 } & $\mathrm{F}$ & 0 & 0 & 3 \\
\hline & $\%$ & 0 & 0 & 100 \\
\hline \multirow{2}{*}{ P9 } & $\mathrm{F}$ & 0 & 0 & 3 \\
\hline & $\%$ & 0 & 0 & 100 \\
\hline \multirow{2}{*}{ P10 } & $\mathrm{F}$ & 0 & 0 & 3 \\
\hline & $\%$ & 0 & 0 & 100 \\
\hline
\end{tabular}

Note:

F:Frequency, \%: Percent

Based on the data above, it was found that the total sum in small-scale testing was in $35 \leq \mathrm{X}$ interval. The interval data was then distributed at the frequency of the assessment. In the distribution chart of the interval rating, the $35 \leq \mathrm{X}$ interval is in appropriate category. Based on that category, it is assumed that the learning model of fundamental motor skill to preschoolers is feasible to be taught in kindergarten. The next step was to see the effectiveness of the learning model to preschoolers. The effectiveness of learning model was assessed by using Likert scale within 1-4 range. The effectiveness assessed in this game was psychomotor effectiveness justified to the kindergarten curriculum.

\section{Large Scale Testing Data}

After conducting the small-scale testing and revising the model as suggested, the next step was conducting largescale testing. Large-scale testing is a trial method using larger scale subjects. The purpose of this test is to find out whether the product developed can be used in a larger subject. The testing was implemented in two places, namely in TK Dharmawanita and TK Perwari. At TK Dharmawanita, the testing was conducted on 20 students who were taught by two teachers. At TK Perwari, the testing was conducted on 15 students who were taught by two teachers. There were three data obtained in this testing, namely(1) observation data of the developed model in its implementation, (2) the data of the effectiveness of learning model in its implementation, (3) input data on the developed model after being implemented in kindergarten. The largescale testing data was obtained from questionnaire given to the experts. The data was then processed by using Likert 
scale. The following table presents the large-scale testing data.

Table 5. Frequency Distribution of Assessment Given By Expert and Teacher At Each Game In Large-Scale Testing

\begin{tabular}{|c|c|c|c|c|}
\hline \multirow{3}{*}{ Game } & & \multicolumn{3}{|l|}{ Category } \\
\hline & & Less & Fairly & Appropriate \\
\hline & & & & \\
\hline \multirow{2}{*}{$\mathrm{P} 1$} & $\mathrm{~F}$ & 0 & 0 & 4 \\
\hline & $\%$ & 0 & 0 & 100 \\
\hline \multirow{2}{*}{$\mathrm{P} 2$} & $\mathrm{~F}$ & 0 & 0 & 4 \\
\hline & $\%$ & 0 & 0 & 100 \\
\hline \multirow{2}{*}{ P3 } & $\mathrm{F}$ & 0 & 0 & 4 \\
\hline & $\%$ & 0 & 0 & 100 \\
\hline \multirow{2}{*}{ P4 } & $\mathrm{F}$ & 0 & 0 & 4 \\
\hline & $\%$ & 0 & 0 & 100 \\
\hline \multirow{2}{*}{ P5 } & $\mathrm{F}$ & 0 & 0 & 4 \\
\hline & $\%$ & 0 & 0 & 100 \\
\hline \multirow{2}{*}{6} & $\mathrm{~F}$ & 0 & 0 & 4 \\
\hline & $\%$ & 0 & 0 & 100 \\
\hline \multirow{2}{*}{ P7 } & $\mathrm{F}$ & 0 & 0 & 4 \\
\hline & $\%$ & 0 & 0 & 100 \\
\hline \multirow{2}{*}{ P8 } & $\mathrm{F}$ & 0 & 0 & 4 \\
\hline & $\%$ & 0 & 0 & 100 \\
\hline \multirow{2}{*}{ P9 } & $\mathrm{F}$ & 0 & 0 & 4 \\
\hline & $\%$ & 0 & 0 & 100 \\
\hline \multirow{2}{*}{ P10 } & $\mathrm{F}$ & 0 & 0 & 4 \\
\hline & $\%$ & 0 & 0 & 100 \\
\hline
\end{tabular}

Note:

F: Frequency \%: Percent

Based on the data above, it was known that the total sum on large-scale testing lied at $35 \leq \mathrm{X}$ interval. The interval data was then distributed at the frequency of the assessment. In the distribution chart of the interval rating, the $35 \leq \mathrm{X}$ interval is in appropriate category. Based on that category, it was concluded that the developed model is suitable to be taught to A group in kindergarten. From the results of large scale testing which its execution was recorded on a $\mathrm{CD}$, the researcher collected some experts' response. Here are the experts' responses on the implementation of large-scale testing.

Table 5. Experts' Input on the Developed Learning Model on Large Scale Testing

\begin{tabular}{ll}
\hline Expert & $\begin{array}{l}\text { Input on the Motor Skill Learning } \\
\text { Model Using Game and fun Game }\end{array}$ \\
\hline Expert 1 & Very Good \\
\hline Expert 2 & Very Good \\
\hline Teacher 1 & Very Good \\
\hline Teacher 2 & Very Good \\
\hline
\end{tabular}

\section{CONCLUSION}

The Development of Game-based fundamental motor skill learning model through animal-themed using research and Development design produced the games, namely: 1) Run and Throw the Ball Game 2) Leaping Games, 3) Color Equal Game, 4) Mice Hole Game, 5) Throwing ball game,
6) "Undur-undur" game, 7) Snake Hunting game, 8) Tiger and Goat game, 9) Shuttle run and throw ball game, and 10) Jumping Rope Game.

The development of Game-Based fundamental motor skill learning model using "Fun and Game" is effective to be implemented in kindergarten to train the preschoolers' basic motion skills. The development of Game-Based fundamental motor skill learning model using "Fun and Game" gets good response from the preschoolers.

\section{REFERENCES}

[1] A, Komaini, Fundamental Motor Skills of Preschoolers (A Survey Study of the Influence of Financial Condition, Playing Activity, and Nutritional Status). IOP Publishing. IOP Conf. Series: Materials Science and Engineering 180 (2017) $012156 \quad$ doi:10.1088/1757899X/180/1/012156

[2] Sugiyono. "Metode penelitian kuantitatif kualitatif dan R \& D”. Bandung: Alfabeta. 2011. pp. 17. 